\title{
Radiative forcing of haze during a forest fire in Spain
}

\author{
A. I. Calvo, ${ }^{1}$ V. Pont,${ }^{2}$ A. Castro, ${ }^{1}$ M. Mallet, ${ }^{2}$ C. Palencia, ${ }^{1}$ J. C. Roger, ${ }^{3}$ P. Dubuisson, ${ }^{4}$ \\ and R. Fraile ${ }^{1}$ \\ Received 1 April 2009; revised 13 November 2009; accepted 8 December 2009; published 29 April 2010.
}

[1] Intense fires occurred in northwestern Spain on 6 September 2000, filling a valley with smoke haze. Aerosol size distribution measurements were performed during 1 day with a thermal inversion, so the aging process of the smoke aerosol could be closely monitored. In $3.5 \mathrm{~h}$, the fine aerosol increased up to $0.06 \mu \mathrm{m}$ in the geometric median diameter of the fine mode. This aging process enhanced the scattering ability of aerosols. On the basis of several hypotheses on the data obtained, shortwave radiative forcing at surface level, at top level, and in the atmosphere was estimated: instantaneous surface forcing reached up to between -80.4 and $-67.4 \mathrm{~W} / \mathrm{m}^{2}$, top of the atmosphere (TOA) instantaneous forcing reached up to between -23.4 and $+4.9 \mathrm{~W} / \mathrm{m}^{2}$, and instantaneous atmosphere forcing reached up to between +44.2 and $+85.3 \mathrm{~W} / \mathrm{m}^{2}$. The study reveals not only the absorption of solar radiation in the atmosphere by smoke aerosols but also an aerosol-induced case study, where TOA cooling forcing shifts to warming for specific aerosol single scattering albedo. The daily mean heating rate of the smoke haze was estimated at $5.9 \pm 0.6 \mathrm{~K} / \mathrm{d}$.

Citation: Calvo, A. I., V. Pont, A. Castro, M. Mallet, C. Palencia, J. C. Roger, P. Dubuisson, and R. Fraile (2010), Radiative forcing of haze during a forest fire in Spain, J. Geophys. Res., 115, D08206, doi:10.1029/2009JD012172.

\section{Introduction}

[2] Biomass burning commonly refers to the burning of forests, grasslands, and agricultural lands after harvesting for the purpose of land clearing and land conversion. This process is an important source of atmospheric particulate matter and gases in various parts of the world [Crutzen and Andreae, 1990; Andreae et al., 1994; Intergovernmental Panel on Climate Change, 2001].

[3] Biomass burning is considered to have potential effects on precipitation, cloud properties, and radiative balance [Penner et al., 1992; Hobbs et al., 1997; Lin et al., 2006; Intergovernmental Panel on Climate Change, 2007]. In addition, forest fires, which represent one form of biomass burning, are also an important source of atmospheric pollutants [von Hoyningen-Huene et al., 1998; Ikegami et al., 2001; Lee et al., 2005].

[4] Furthermore, the aerosol size distribution can account for aerosol population dynamics, the processes involved in their production and removal, and the transformation of their size, which influences their lifetime, optical properties, and radiative effects [Huebert et al., 1996] as well as the impact they have on the environment [Wardoyo et al., 2007]. Size

\footnotetext{
${ }^{1}$ Departamento de Física, Universidad de León, León, Spain.

${ }^{2}$ Laboratoire d'Aérologie, OMP, Université de Toulouse III, CNRS, UPS, Toulouse, France.

${ }^{3}$ Laboratoire de Meteorologie Physique, OPGC, Aubière, France.

${ }^{4}$ Laboratoire d'Optique Atmosphérique, Lille, France.

Copyright 2010 by the American Geophysical Union. 0148-0227/10/2009JD012172
}

distribution strongly depends on the sources (burning processes and burning conditions) and sinks, as well as on the meteorological processes prevailing during their lifetime. Most atmospheric aerosols from biomass burning have a diameter of less than $2.5 \mu \mathrm{m}$ [Ferge et al., 2005; Wieser and Gaegauf, 2005].

[5] Numerous studies deal with the aging processes of particles produced by biomass burning [Liousse et al., 1995; Anderson et al., 1996; Reid et al., 1998; Fiebig et al., 2003; Hobbs et al., 2003]. All of them conclude that the aging of smoke particles may have a significant effect on their physical and chemical (and consequently optical) properties. The growth of particles in size and mass occurs generally on fairly short time scales as little as $2 \mathrm{~h}$ after emission [Abel et al., 2003; Reid et al., 2005]. There are more modest increases, on time scales of days [Hobbs et al., 1996]. Various mechanisms may explain smoke particle aging, including water uptake [Hobbs et al., 1997], condensation of volatile organic species [Reid et al., 1998; Abel et al., 2003], and coagulation [Westphal and Toon, 1991; Radke et al., 1995; Fiebig et al., 2003].

[6] Previous studies deal with the dependence of radiative forcing on fire aerosol aging [Formenti et al., 2002; Fiebig et al., 2003]. The magnitude of the solar radiative forcing of aerosol containing an absorbing component depends on the concentration of this component [Haywood and Shine, 1995], on the number-size distribution of the aerosol [Chylek and Wong, 1995], and on its state of mixture [Wendisch et al., 2001]. At present, radiative direct forcing of burning continues to be at a medium to low level of scientific understanding, as major uncertainties remain on emission sources 


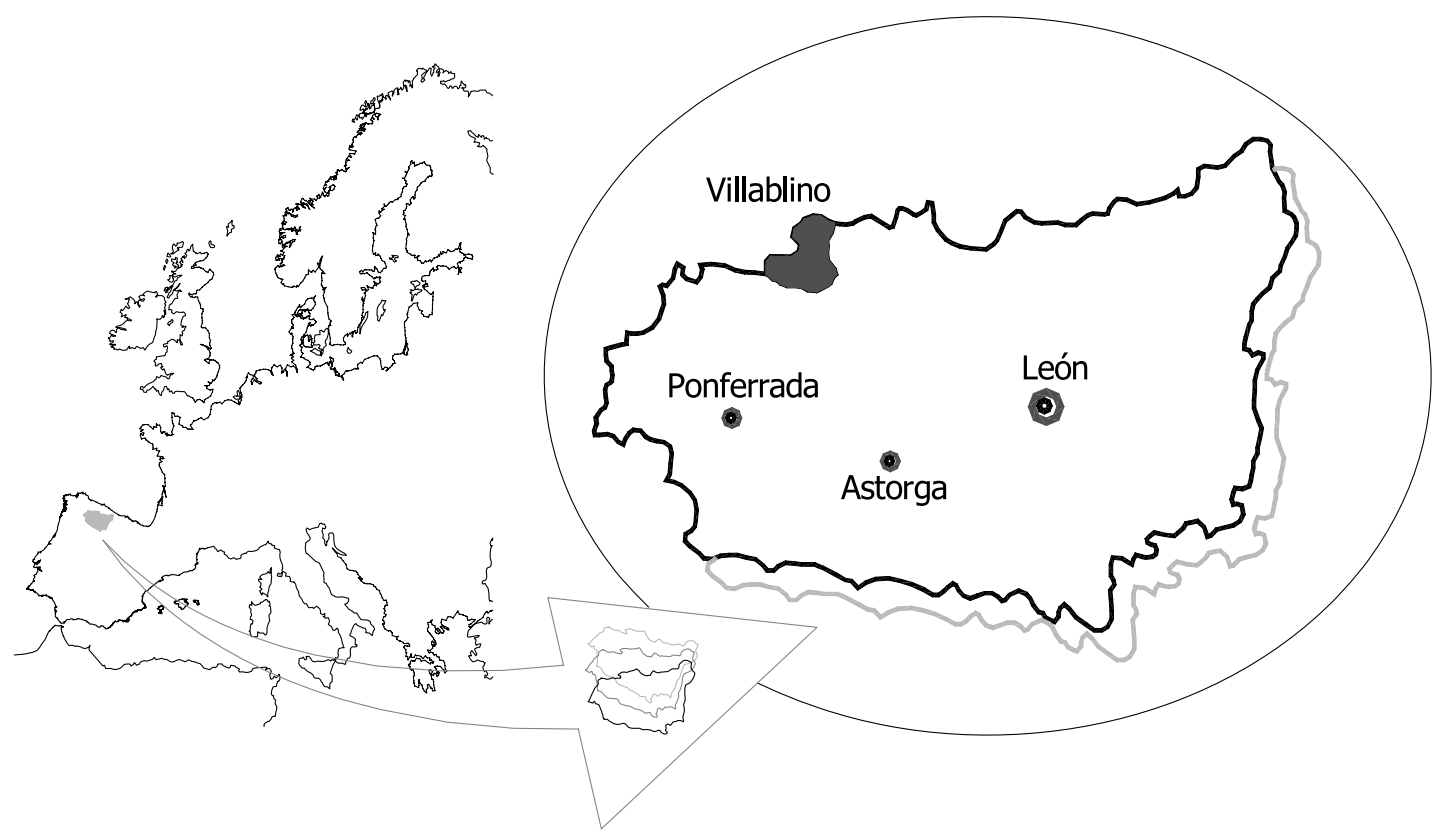

Figure 1. Study zone in the province of León, Spain.

and its aging [Intergovernmental Panel on Climate Change, 2007].

[7] This paper presents the results of a study on shortwave (SW) radiative forcings versus particle size distributions measured during one of the 8 days of a forest fire close to the town of Villablino in the province of León, Spain. The concentration and size distribution of the particles were measured downwind with a laser spectrometer at various distances of the fire. The main aim of this study was to analyze the temporal evolution of radiative forcing in relation to forest fire haze aging.

[8] The estimation of the aerosol radiative forcing was carried out using the discrete ordinate Radiative Transfer Model Global Atmospheric ModEl (RTM GAME) [Dubuisson et al., 1996, 2004]. Radiative transfer computations depend on several parameters, such as the spectral values of solar radiation incident on the atmosphere, the spectral variation of the aerosol optical depth (AOD), single scattering albedo (SSA), asymmetry parameter $(g)$, surface albedo, and associated vertical profiles of atmospheric properties (temperature, relative humidity, and ozone concentration).

[9] All of this information has been obtained from various sources; the methodology and the assumptions used to describe the optical properties of the fire aerosol are described in section 3.4. The methodology used for computing the aerosol radiative impact is described in detail by Mallet et al. [2006, 2008] and Roger et al. [2006]. Direct clear-sky radiative forcing is presented and discussed in sections 3.4 and 4 , respectively.

\section{Study Zone}

[10] In the past few decades the world has witnessed a growing trend in the number of forest fires, and Spanish forests are no exception. There has been a steady increase in the number of cases recorded, although there has been a gradual decrease in the land area affected by fires. In Spain the years in which the largest areas were burnt were 1978, 1985, 1989, and 1994 with burnt areas of 4,395, 4,845, 4,267 , and $4,376 \mathrm{~km}^{2}$, respectively. However, if we consider the number of fires, the years with the highest number were 1995, 1997, and 2000 with 25,827, 22,319, and 24,118 cases, respectively (Ministry of the Environment, Madrid, 2007, details available at http://www.mma. es/secciones/biodiversidad/defensa incendios/estadisticas incendios/pdf). The years with more burnt land were years of persistent drought, especially during the summer months. In 2005,2006 , and 2007, burnt areas and number of forest fires decreased, recorded as $1,886,1,553$, and $861 \mathrm{~km}^{2}$, and $25,492,16,334$, and 10,932 cases, respectively. (Related data from the Ministry of the Environment, Madrid, are available at the following websites: http://www.mma.es/secciones/ biodiversidad/defensa incendios/estadisticas incendios/pdf/ publicacion_2006.pdf, and http://www.mma.es/secciones/ biodiversidad/defensa_incendios/estadisticas_incendios/pdf/ incendiosforestales $20 \overline{07}$.pdf).

[11] In 1998 in the province of León, Spain, 694 forest fires occurred and $158 \mathrm{~km}^{2}$ were burned; in 1999, 757 forest fires in the province devastated $139 \mathrm{~km}^{2}$; and in 2000,1050 forest fires burned $357 \mathrm{~km}^{2}$. In 2005, 2006, and 2007, the trend in León was similar to that observed for the whole of Spain; indeed, 166, 62, and $32 \mathrm{~km}^{2}$ of León were burned in 920,521 , and 384 fires, respectively.

[12] The district of Villablino $\left(42^{\circ} 56^{\prime} 20^{\prime \prime} \mathrm{N}, 6^{\circ} 19^{\prime} 00^{\prime \prime} \mathrm{W}\right)$ lies in the region of Laciana, in the northwest section of the province of León, Spain (Figure 1), in the Cantabrian Mountain Range, with altitudes of between 900 and 1,300 m. A mountainous area with high valleys, it is exploited for agricultural purposes, forestry, and industry, especially coal mining.

[13] On 7 September 2000 a forest fire was deliberately set and lasted for 8 days. A vast area was affected, including 
Table 1. Geographic Location of the Sampling Points, Times of the Samplings, and Altitude Correction Factor

\begin{tabular}{|c|c|c|c|c|c|c|c|}
\hline $\begin{array}{l}\text { Sampling } \\
\text { Points }\end{array}$ & Time (UTC) & Location & Longitude & Latitude & $\begin{array}{l}\text { Distance to } \\
\text { the Fire }(\mathrm{m})\end{array}$ & $\begin{array}{l}\text { Altitude } \\
\text { (m) }\end{array}$ & $\begin{array}{c}\text { Altitude } \\
\text { Correction Factor }\end{array}$ \\
\hline B0 & 1150 & Cuevas del Sil & $6^{\circ} 23^{\prime} 36^{\prime \prime} \mathrm{W}$ & $42^{\circ} 53^{\prime} 43^{\prime \prime} \mathrm{N}$ & 3800 & 890 & 0.899 \\
\hline B1 & 1650 & Cuevas del Sil & $6^{\circ} 23^{\prime} 36^{\prime \prime} \mathrm{W}$ & $42^{\circ} 53^{\prime} 43^{\prime \prime} \mathrm{N}$ & 3800 & 890 & 0.899 \\
\hline $\mathrm{C} 0$ & 1226 & Villarino del Sil & $6^{\circ} 21^{\prime} 45^{\prime \prime} \mathrm{W}$ & $42^{\circ} 54^{\prime} 34^{\prime \prime} \mathrm{N}$ & 2700 & 1066 & 0.880 \\
\hline $\mathrm{C} 1$ & 1554 & Villarino del Sil & $6^{\circ} 21^{\prime} 45^{\prime \prime} \mathrm{W}$ & $42^{\circ} 54^{\prime} 34^{\prime \prime} \mathrm{N}$ & 2700 & 1066 & 0.880 \\
\hline D0 & 1307 & $\mathrm{Km} 55$ on road between Villarino and Cuevas del Sil & $6^{\circ} 22^{\prime} 36^{\prime \prime} \mathrm{W}$ & $42^{\circ} 54^{\prime} 01^{\prime \prime} \mathrm{N}$ & 3200 & 900 & 0.898 \\
\hline D1 & 1625 & $\mathrm{Km} 55$ on road between Villarino and Cuevas del Sil & $6^{\circ} 22^{\prime} 36^{\prime \prime} \mathrm{W}$ & $42^{\circ} 54^{\prime} 01^{\prime \prime} \mathrm{N}$ & 3200 & 900 & 0.898 \\
\hline
\end{tabular}

the districts of Villablino and Palacios del Sil. The land that was burnt $\left(10.1 \mathrm{~km}^{2}\right)$ included shrub $\left(7.61 \mathrm{~km}^{2}\right)$ and wooded land $\left(2.69 \mathrm{~km}^{2}\right)$. Samplings of aerosols at different points close to the fire were taken on 7 September.

\section{Methodology}

\subsection{Measurement Equipment}

[14] A laser spectrometer was used to measure the size spectrum of aerosols (Passive Cavity Aerosol Spectrometer Probe, PMS Model PCASP-X; Particle Measuring Systems, Inc., Boulder, Colorado) between sizes 0.1 and $10 \mu \mathrm{m}$ ). This instrument, an optical particle counter, detects single particles and groups them into different sizes by measuring the intensity of the light that the particles scatter when passing through a laser light beam (He-Ne, $632.8 \mathrm{~nm})$. Before the field campaign, the instrument was calibrated by Particle Metrics, Inc. (also of Boulder, Colorado). A series of corrections to the counts made by the spectrometer are necessary to establish the exact number of particles by unit of volume sampled in each channel.

[15] 1. The value of the sample volume has to be adjusted according to the altitude of the sampling point. We used a correction for the adjustment of flowmeter versus altitude, as recommended by the manufacturer. In this case, the measurements were carried out at different points, so a different correction factor was applied for each sampling point, as shown in Table 1.

[16] 2. This optical counter was calibrated with latex particles with a refractive index of $1.58-0.0 \mathrm{i}$. To retrieve the exact number concentration versus exact size intervals, we corrected raw size bins, using a program based on Mie Theory implemented with a computer code developed by Bohren and Huffman [1983], for fire aerosols mean refractive index (1.49-0.013i). This value corresponds to AERONET Sun photometer retrieval at $675 \mathrm{~nm}$ (see section 3.4). After correction, the number of particles is measured in a size range from 0.09 to $24 \mu \mathrm{m}$.

[17] As we refer to an unmeasured refractive index, we calculate the sensitivity of the size range to the variability of the refractive index. We refer to various refractive indexes for biomass burnings given by Dubovik et al. [2002]. The real part varies between 1.47 and 1.52, while the imaginary part varies between 0.00093 and 0.021 . We tested 13 possible refractive indexes and found a variability of $\pm 9 \%$ of the particle diameter for the fine mode.

[18] Each sampling lasted 10 min, subsamples being taken every $60 \mathrm{~s}$. The subsamples were corrected, as described above. The mean of the 10 corrected subsamples was considered the final value for a particular sampling point.

\subsection{Sampling Points and Data Gathering}

[19] Early in the morning of 7 September, the Department for the Environment of the Junta de Castilla y León (the regional government) informed us of the forest fire close to Villablino. The sampling points, as defined in Figure 2, were approached one after another by an instrumentequipped car. In fact, the PCASP device was installed on the roof of the car so that the samples could be collected with the isokinetic probe of the spectrometer at $3 \mathrm{~m}$ above the ground at each sampling point.

[20] Before deciding on which points to use for the aerosol samplings, we noted that a light wind blowing down the valley to the southwest, and that the smoke plume drifted in that direction. There were three different sampling points: at Cuevas del Sil, at Villarino del Sil, and at the kilometer 55 point on the road between Villarino and Cuevas del Sil. Two measurements were carried out at different times at each point for a total of six observations. The sampling points were named $\mathrm{B}, \mathrm{C}$, and $\mathrm{D}$, followed by 0 if the measurement was taken in the morning or by 1 if it was carried out in the afternoon (Table 1).

[21] Between the morning samplings and the afternoon samplings, the atmospheric conditions changed. The development of the fire did not vary greatly, although the valley suddenly filled with smoke and visibility was considerably reduced. Additional measurements carried out at all sampling points were temperature at surface level, surface wind speed, and surface wind direction (Table 2).

\subsection{Meteorological Analysis}

[22] Synoptic maps reveal that an Atlantic high was over the study zone when the fire began (6 September). The next day a large part of the Iberian Peninsula was under the influence of a flat low located in the western Mediterranean area. With diurnal warming the synoptic map at 1200 UTC revealed a thermal low over the Peninsula, but there was an intense high of warm air at high levels. Twelve hours later, there was clearly a high-pressure situation, with several highpressure areas in the north of the Peninsula generating major atmospheric stability (http://www.infomet.am.ub.es/arxiu/ mapes_fronts/). This hindered the dispersion of pollutants, particularly in the case of the smoke particles produced by the forest fire.

[23] The high pressure both on the ground and at high levels began on 1 September and remained stable until 17 September over the Iberian Peninsula. The great stability, combined with no rain, reduced the ability of the atmosphere to disperse pollutants. Temperatures were unusually high for the study zone in that time of year (daily maximum values of $30^{\circ} \mathrm{C}$ and daily minimum values of $14^{\circ} \mathrm{C}$ on 7 September). 


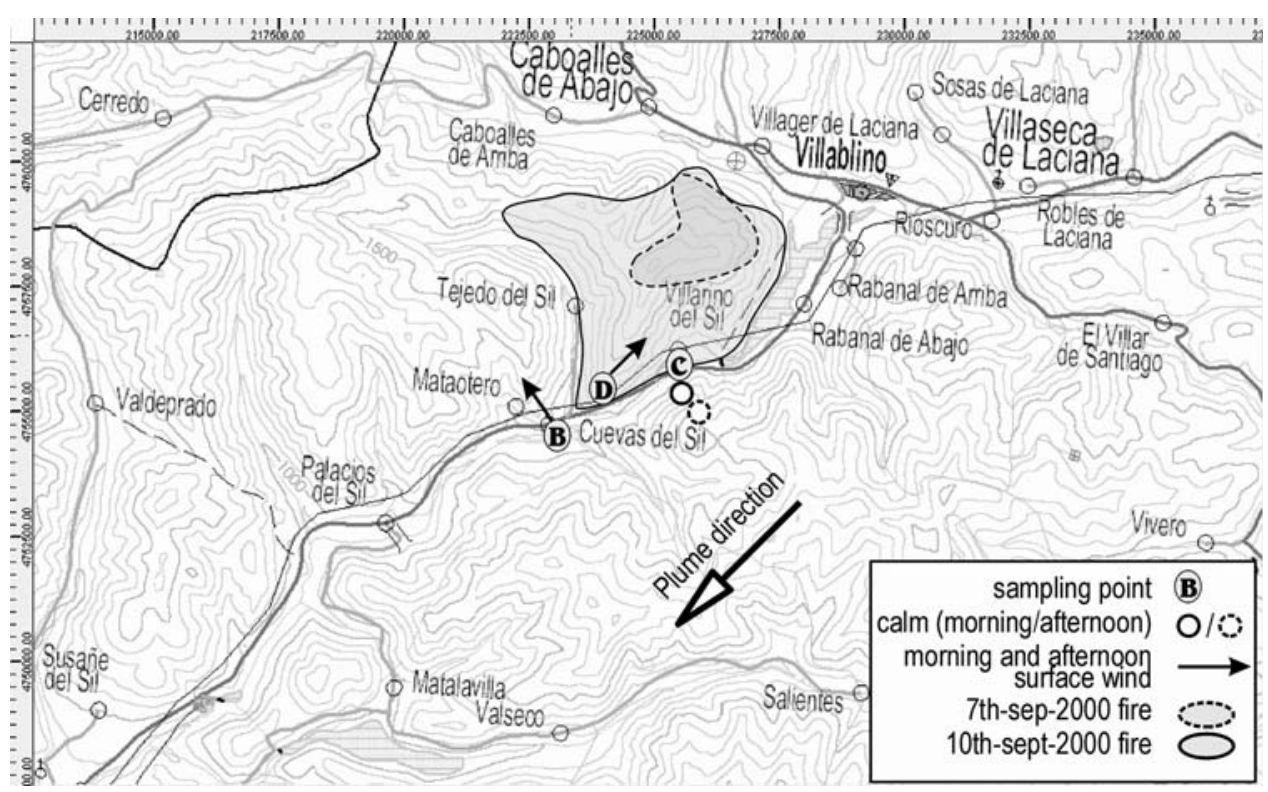

Figure 2. Map of the study zone with the sampling points (morning and afternoon), plume direction, and surface wind direction.

[24] The University of Wyoming provided data from radio soundings carried out over La Coruña and Santander, the two closest radio sounding stations. Analysis of the radio soundings carried out on 7 September 1200 UTC shows a particularly interesting subsidence inversion located at 1,192 and $1,691 \mathrm{~m}$ above the ground at the stations, respectively, caused by the high pressure over the Iberian Peninsula. On the basis of the Holzworth methodology [Holzworth, 1967], boundary layer heights were estimated at around 1,720 and 1,550 $\mathrm{m}$ above ground level, respectively, in La Coruña and Santander. Even though the radio soundings were not carried out directly over the fire area, they provided information on the stable meteorological situation: subsidence phenomena explain the low dispersion of fire aerosols that generated the fire haze and reduced visibility over the study area. For computing the radiative forcing of this aging haze, the fire aerosols are supposed to be stuck within the boundary layer. The vertical variability of the relative humidity from these radio soundings is useful as input data for the GAME module, so that radiative forcing should be computed with the most realistic sensitivity of the aerosol to the humidity variability.

\subsection{Radiative Forcing Modeling}

[25] Radiative transfer computations depend on optical aerosol parameters such as AOD, SSA, and $g$. In this study, estimates of these optical parameters were based on the Mie theory, considering the aerosol size distribution together with the refractive index. As a result, SSA and $g$ were calculated at the seven wavelengths used in the GAME radiative transfer model.

[26] As no refractive index measurement was available during the study period, it was necessary to use similar fire activity in northwestern Spain detected by the AERONET photometer in Palencia $\left(41^{\circ} \mathrm{N}, 4^{\circ} \mathrm{W}\right)$ to retrieve the specific smoke refractive index. AERONET (AErosol RObotic NETwork) is an optical ground-based aerosol-monitoring network and data archive supported by the NASA Earth Observing System and expanded by federation with many nonNASA institutions (http://aeronet.gfsc.nasa.gov). Hodzic et al. [2007] describe a number of exceptionally large wildfires over the Iberian Peninsula from 1 to 15 August 2003. These wildfires occurred in the same region as the case study in this paper. Assuming that the vegetation source is the same in Palencia and Villablino, we can consider that the mean refractive index retrieved from the Sun photometer AERONET measurements on 6 August 2003 in Palencia is representative of the same burnt vegetation. The high Angstrom coefficient (1.36) reveals the presence of smoke aerosols; indeed, Reid et al. [1998] found a decrease of Angstrom coefficients from 2.2 to 1.2 during smoke aging, which strengthens the hypothesis that measurements in Palencia corresponded to smoke particles aging. The spectral dependence, retrieved by AERONET, of the mean refractive index used in Mie calculations is given in Table $3 \mathrm{a}$. The refractive index values are consistent with those for the composite aged regional haze dominated by biomass burning aerosol [Haywood et al., 2003]. The real part of the refractive index is also in line with that found by Yamasoe et al. [1998] for biomass burning aerosol in Brazil.

[27] As mentioned above, aerosol size distributions are also required for calculating optical parameters. PCASP

Table 2. Meteorological Data at the Sampling Points

\begin{tabular}{ccccc}
\hline $\begin{array}{c}\text { Sampling } \\
\text { Points }\end{array}$ & $\begin{array}{c}\text { Time } \\
(\text { UTC) }\end{array}$ & $\begin{array}{c}\text { Surface } \\
\text { Temperature } \\
\left({ }^{\circ} \mathrm{C}\right)\end{array}$ & Surface Wind Direction & $\begin{array}{c}\text { Surface Wind } \\
\text { Speed }(\mathrm{m} / \mathrm{s})\end{array}$ \\
\hline B0 & 1150 & 35 & SE-NW & Calm-2.2 \\
B1 & 1650 & 31 & SE-NW & 1.3 \\
C0 & 1226 & 35 & - & Calm \\
C1 & 1554 & 36 & - & Calm \\
D0 & 1307 & 35 & SW-NE & Calm-2.6 \\
D1 & 1625 & 35 & SW-NE & Calm \\
\hline
\end{tabular}


Table 3a. Refractive Index With Real and Imaginary Parts Retrieved From AERONET Measurements for the Total Distribution ${ }^{\mathrm{a}}$

\begin{tabular}{ccc}
\hline Wavelengths $(\mathrm{nm})$ & Values REFR $\pm \Delta$ & Values REFI $\pm \Delta$ \\
\hline 440 & $1.47 \pm 0.07$ & $0.017 \pm 0.006$ \\
670 & $1.49 \pm 0.06$ & $0.013 \pm 0.006$ \\
870 & $1.51 \pm 0.06$ & $0.012 \pm 0.004$ \\
\hline
\end{tabular}

${ }^{\mathrm{a}} \mathrm{REFR}$ and REFI, real and imaginary parts of the refractive index, respectively; they represent the light scattering and absorption properties of aerosol particles, respectively. AERONET, Aerosol Robotic Network.

field measurements provide the lognormal number-size distribution, from which parameters such as the geometric mean diameter (GMD), the geometric standard deviation $\left(\sigma_{\mathrm{g}}\right)$, and the total number are estimated. These number-size distributions are bimodal, with fine mode particles $(<1 \mu \mathrm{m})$ and a small fraction of coarse mode particles $(>1 \mu \mathrm{m})$ [Hodzic et al., 2007].

[28] In the case of the AOD parameter, we used the only Moderate Resolution Imaging Spectroradiometer (MODIS) data on 7 September 2000 (251st Julian day) over the Villablino region at the $550 \mathrm{~nm}$ wavelength. Figures 3 and 4 show the fire event in question captured by the MODIS sensor at 1125 UTC. Under the red circles representing the study zone, AOD reached about 0.31 , revealing the presence of nonnegligible aerosols on the vertical profile of the atmosphere (Figure 3). The fine to coarse AOD ratio (Figure 4) reveals the predominant role of fine aerosols in total extinction, typically observed in combustion aerosols.

[29] Once the necessary parameters had been obtained, the spectral optical properties could be modeled. Tables $3 \mathrm{~b}$ and $3 \mathrm{c}$ show fine, coarse, and total size distribution SSA and $g$ for AERONET wavelengths $(440,670$, and $870 \mathrm{~nm})$ with standard deviations of 0.04 and $0.01 \mu \mathrm{m}$ for total size distribution, regardless of the wavelengths considered. Our values are in the range of those obtained by Cachorro et al. [2000] in northern and central Spain. Additionally, our values are similar to those given by Procopio et al. [2003], calculated for smoke aerosols in the Amazon and Africa. Similarly, SSA values are in the range of those retrieved by AERONET for biomass burning particles in Amazonian forests and in African savannas [Dubovik et al., 2002].

[30] The optical properties described here were used together with temperature, ozone, and relative humidity vertical profiles as inputs in the GAME radiative transfer model, detailed by Dubuisson et al. [2004], to estimate the instantaneous SW clear-sky direct radiative forcing of smoke aerosols. GAME accounts for the scattering and absorption ability of particles and gases. Absorption by gases $\left(\mathrm{H}_{2} \mathrm{O}\right.$, $\mathrm{CO}_{2}, \mathrm{O}_{2}$, and $\mathrm{O}_{3}$ ) was treated by using the correlated $k$-distribution, with a line by line code [Dubuisson et al.,
1996], and multiple scattering effects were treated by using the discrete ordinates method [Stamnes et al., 1988].

[31] This method provides an accurate treatment of scattering and absorption by aerosols, clouds and molecules. Upward and downward net radiative fluxes are calculated over the spectral solar, ranging from 2,500 to $50,000 \mathrm{~cm}^{-1}$, with a $100 \mathrm{~cm}^{-1}$ spectral resolution. Calculations of radiative fluxes integrated over the entire SW region were performed at the specific sampling time. Owing to the particle size (Table 4), the effects of smoke aerosols on longwave fluxes were expected to be low.

[32] On the basis of these fluxes, we calculated the instantaneous clear-sky direct aerosol-induced forcing at the bottom of atmosphere (BOA), $\triangle F B O A$, and at the top of the atmosphere (TOA, $10 \mathrm{~km}$ in this case), $\triangle \mathrm{FTOA}$. The first represents the effect of particles on the net SW radiation fluxes reaching the surface and the second represents the radiation fluxes reflected back to space by aerosols. BOA and TOA forcings were calculated as follows:

$$
\begin{gathered}
\Delta \mathrm{FBOA}=\operatorname{FBOA}(\mathrm{w})^{\downarrow}-\operatorname{FBOA}(\mathrm{o})^{\downarrow}, \\
\Delta \mathrm{FTOA}=-\left(\operatorname{FTOA}(\mathrm{w})^{\uparrow}-\operatorname{FTOA}(\mathrm{o})^{\uparrow}\right),
\end{gathered}
$$

where $\operatorname{FBOA}(w)^{\downarrow}$ and $\operatorname{FBOA}(\mathrm{o})^{\downarrow}$ are the downward net radiative fluxes simulated at the surface with $(\mathrm{w})$ and without (o) aerosols, respectively. FTOA(w) ${ }^{\uparrow}$ and FTOA(o $)^{\uparrow}$ are the upward net radiative fluxes simulated at the top of atmosphere with (w) and without (o) aerosols, respectively. With this convention, a positive sign of $\Delta \mathrm{F}$ implies an aerosolwarming effect. Finally, atmospheric forcing, $\triangle$ FATM, was calculated using the following formula:

$$
\Delta \mathrm{FATM}=\Delta \mathrm{FTOA}-\Delta \mathrm{FBOA} .
$$

$\triangle$ FATM represents the possible absorption of solar radiations due to absorbing properties of fire particles within the atmospheric layer containing the aerosols. The modeled results are discussed in section 4.

\subsection{GAME Reliability}

[33] For a given AOD, radiative forcing results are dependent on the variability of the surface albedo, on SSA and $g$ parameters, and therefore indirectly on the size distribution and refractive index. Error budgets have to be mentioned to bound results. First, the GAME code has been used in an intercomparison exercise [Halthore et al., 2005].

\begin{tabular}{|c|c|c|c|c|c|c|c|c|c|}
\hline \multirow[b]{2}{*}{ Sampling Points } & \multicolumn{3}{|c|}{ SSA fine } & \multicolumn{3}{|c|}{ SSA coarse } & \multicolumn{3}{|c|}{ SSA total } \\
\hline & $440 \mathrm{~nm}$ & $670 \mathrm{~nm}$ & $870 \mathrm{~nm}$ & $440 \mathrm{~nm}$ & $670 \mathrm{~nm}$ & $870 \mathrm{~nm}$ & $440 \mathrm{~nm}$ & $670 \mathrm{~nm}$ & $870 \mathrm{~nm}$ \\
\hline B0 & 0.89 & 0.87 & 0.84 & 0.71 & 0.82 & 0.86 & 0.86 & 0.85 & 0.85 \\
\hline $\mathrm{C} 0$ & 0.89 & 0.88 & 0.86 & 0.73 & 0.84 & 0.89 & 0.89 & 0.87 & 0.87 \\
\hline D0 & 0.88 & 0.87 & 0.84 & 0.67 & 0.77 & 0.81 & 0.81 & 0.81 & 0.77 \\
\hline $\mathrm{C} 1$ & 0.91 & 0.91 & 0.89 & 0.74 & 0.85 & 0.90 & 0.87 & 0.88 & 0.89 \\
\hline D1 & 0.90 & 0.89 & 0.87 & 0.74 & 0.85 & 0.90 & 0.88 & 0.88 & 0.88 \\
\hline B1 & 0.90 & 0.89 & 0.87 & 0.72 & 0.84 & 0.90 & 0.88 & 0.88 & 0.88 \\
\hline
\end{tabular}
The results of this exercise indicated that GAME is accurate

Table 3b. Single Scattering Albedo 
Table 3c. Asymmetry Parameter $g$ Calculated at the Same Wavelengths From the Mie Theory

\begin{tabular}{|c|c|c|c|c|c|c|c|c|c|}
\hline \multirow[b]{2}{*}{ Sampling Points } & \multicolumn{3}{|c|}{$g$ fine } & \multicolumn{3}{|c|}{$g$ coarse } & \multicolumn{3}{|c|}{$g$ total } \\
\hline & $440 \mathrm{~nm}$ & $670 \mathrm{~nm}$ & $870 \mathrm{~nm}$ & $440 \mathrm{~nm}$ & $670 \mathrm{~nm}$ & $870 \mathrm{~nm}$ & $440 \mathrm{~nm}$ & $670 \mathrm{~nm}$ & $870 \mathrm{~nm}$ \\
\hline B0 & 0.56 & 0.41 & 0.31 & 0.81 & 0.74 & 0.72 & 0.61 & 0.53 & 0.53 \\
\hline $\mathrm{C} 0$ & 0.61 & 0.46 & 0.36 & 0.79 & 0.72 & 0.71 & 0.63 & 0.54 & 0.53 \\
\hline D0 & 0.58 & 0.43 & 0.34 & 0.85 & 0.79 & 0.75 & 0.65 & 0.63 & 0.64 \\
\hline $\mathrm{C} 1$ & 0.66 & 0.52 & 0.41 & 0.78 & 0.72 & 0.71 & 0.68 & 0.60 & 0.59 \\
\hline D1 & 0.62 & 0.47 & 0.37 & 0.78 & 0.72 & 0.71 & 0.64 & 0.55 & 0.55 \\
\hline B1 & 0.62 & 0.47 & 0.37 & 0.80 & 0.73 & 0.71 & 0.64 & 0.53 & 0.54 \\
\hline
\end{tabular}

to a few watt units $(1-3 \mathrm{~W})$ for a flux reaching $1000 \mathrm{~W} \cdot \mathrm{m}^{-2}$. Furthermore, within the framework of the ESCOMPTE experiment for aerosols located in the planetary boundary layer, sensitivity tests have been carried out on the mass, density, mean radius, and refractive index of aerosols controlling the optical properties (SSA and $g$ ) used in GAME [Roger et al., 2006]. The authors defined an uncertainty of $\pm 25 \%$ on the density, $\pm 10 \%$ on the lognormal size distribution parameters (i.e., the mean radius and the standard deviation), $\pm 5 \%$ on the real refractive index, and a range of $\pm 20 \%$ on the imaginary part. In parallel, Roger et al. [2006] applied a $\pm 30 \%$ error to the SSA estimated from the Earth Observing System/MODIS. The results for induced uncertainties reported in this work indicate that the radiative impacts of aerosols are defined with an accuracy of $12 \%$ at BOA, $20 \%$ at TOA, and $16 \%$ in the atmosphere. As AOD values are of the same order of size, these sensitivities are consistent and applied in this study.

\section{Results and Discussion}

[34] The increase in the number of particles in the atmosphere may be seen clearly in Figure 5. In the afternoon

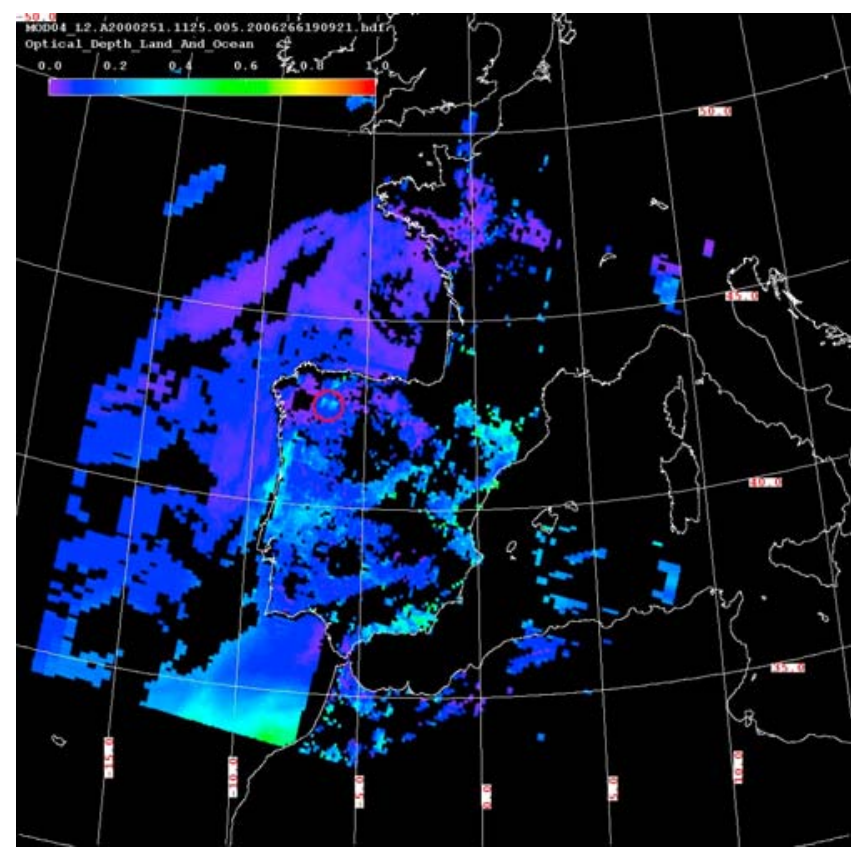

Figure 3. Aerosol optical depth (AOD) from Moderate Resolution Imaging Spectroradiometer (MODIS) data on 7 September 2000 (251st Julian day) at 1125 UTC. The red circle shows the fire event studied. samples, an increase was observed in the total number of fine mode particles, which varied between 1.5 and almost 3 (Table 4) with respect to the morning measurements. If the ratio is evaluated between the number of particles registered in each channel during the afternoon (with thermal inversion) and during the morning (without thermal inversion) (Figure 5), it may be seen that the greatest variations occurred at point $\mathrm{C}$, situated at the head of the valley and close to the fire. In the afternoon, the fire was closer to point $\mathrm{C}$ (and as a result, also to $\mathrm{D}$ and $\mathrm{B}$ ), meaning that particles were advected directly from the fire to sampling point $\mathrm{C}$. The most important differences were registered in the range of the smallest particles, between 0.09 and $0.13 \mu \mathrm{m}$, the number of these particles increasing by an average of 7 times; for diameters of between 0.4 and $3 \mu \mathrm{m}$, however, the increase in the number of particles was higher by an average of 15 times, which led to the average geometric diameter for the fine mode rising from $0.13 \mu \mathrm{m}$ in the morning (without thermal inversion) to $0.19 \mu \mathrm{m}$ in the afternoon (with thermal inversion in point $\mathrm{C}$ ). However, moving down the valley, the increase in the number of fine mode particles was also considerable. At points B and D, an increase in the range of particles with a size of less than $0.13 \mu \mathrm{m}$ was less than that recorded for point $\mathrm{C}$; the increase

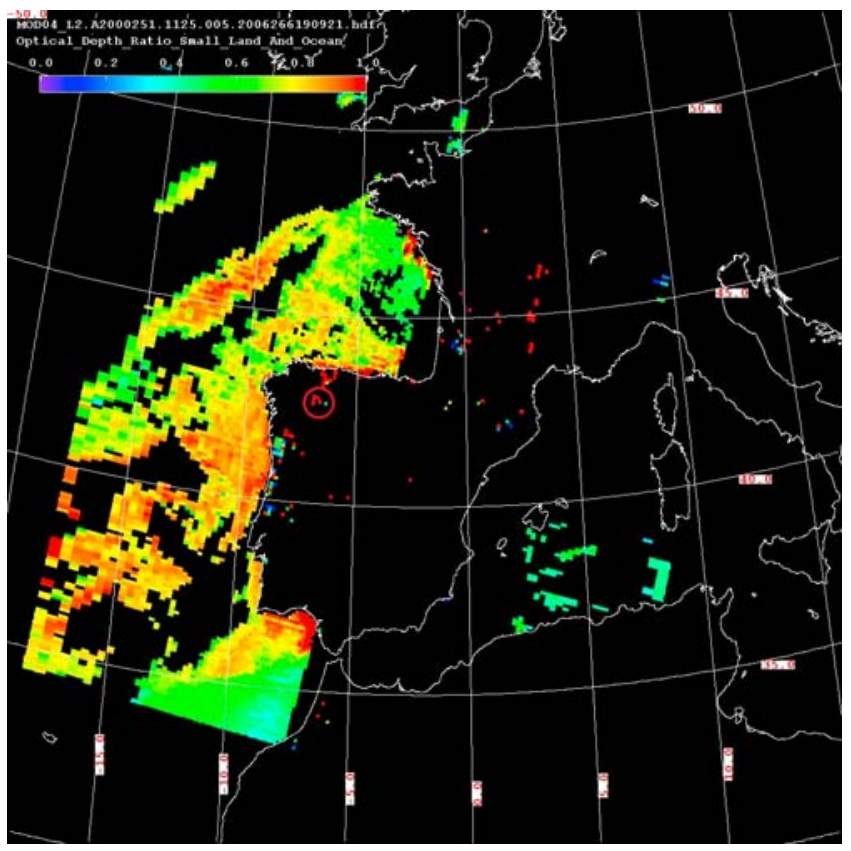

Figure 4. Fine to coarse AOD ratio (MODIS-derived product) on 7 September 2000 at 1125 UTC. The red circle shows the fire event studied. 
Table 4. Geometric Mean Diameter (GMD) and Geometric Standard Deviation $\left(\sigma_{\mathrm{g}}\right)$ of Number Distribution at Sampling Points B, C, and D for the Fine Mode and Coarse Mode

\begin{tabular}{cccccccc}
\hline \multirow{2}{*}{$\begin{array}{c}\text { Sampling } \\
\text { Points }\end{array}$} & \multicolumn{3}{c}{ Fine Mode } & & \multicolumn{3}{c}{ Coarse Mode } \\
\cline { 2 - 4 } \cline { 6 - 8 } \cline { 6 - 8 }$\left(\mathrm{cm}^{-3}\right)$ & $\mathrm{GMD}(\mu \mathrm{m})$ & $\sigma_{\mathrm{g}}$ & & $\mathrm{N}\left(\mathrm{cm}^{-3}\right)$ & $\mathrm{GMD}(\mu \mathrm{m})$ & $\sigma_{\mathrm{g}}$ \\
\hline B0 & 4000 & 0.13 & 1.50 & & 2.5 & 1.20 & 1.60 \\
B1 & 6000 & 0.15 & 1.50 & & 5 & 1.15 & 1.55 \\
C0 & 3200 & 0.13 & 1.55 & & 2.5 & 1.15 & 1.50 \\
C1 & 9000 & 0.19 & 1.45 & & 40 & 1.15 & 1.45 \\
D0 & 2100 & 0.11 & 1.58 & & 1.8 & 1.20 & 1.90 \\
D1 & 6000 & 0.15 & 1.50 & & 8 & 1.15 & 1.45 \\
\hline
\end{tabular}

was also less significant for larger sizes, leading to a GMD of $0.15 \mu \mathrm{m}$ for B and D.

[35] We have mainly attributed this important increase in the number of particles in the afternoon to the fact that the sampling points were closer to the fire, and to the low vertical dispersion caused by the presence of the thermal subsidence inversion. The reason may not be attributed to the evolution of the fire, since during this time span no important changes occurred in the progression of the fire. No quantitative data are available to assess the fire activity; only qualitative visual observations of the fire front by on-field watchers. The fire was observed to progress slowly on the same mountainside, through the same densities of plant species (bushes, 74\% throughout; trees, 26\% throughout). The surface winds measured at every point of observation with a portable anemometer remained slight. In summary, the fire did not increase suddenly as a result of wind action or variation in the combustible material. It is important to remember that the fire began on the day before (6 September) the day on which the samples were taken (7 September), meaning that the experimental measurements taken both in the morning and in the afternoon contain fresh and aged fire aerosols. As a result, the distributions measured in the afternoon have not been corrected, owing to the fact that in both situations (morning and afternoon), the two types of aerosols coexisted (fresh and aged). The only thing that changed radically was the atmospheric situation, which prevented smoke aerosols from dispersing. This discussion is approached from the point of view of the aging processes of the biomass burning aerosol, rather than of the type of fire (flaming or smoldering).

[36] Table 4 shows the main parameters of the number size distribution (total number concentration, GMD, and $\sigma_{\mathrm{g}}$ ) for fine and coarse mode, for each sampling point. The average of GMD with geometric standard deviation for the fine mode was $0.12 \mu \mathrm{m}\left(\sigma_{\mathrm{g}}=1.54\right)$ in the morning samplings and $0.16 \mu \mathrm{m}\left(\sigma_{\mathrm{g}}=1.48\right)$ in the afternoon samplings. The average GMD with geometric standard deviation for the coarse mode was $1.18 \mu \mathrm{m}\left(\sigma_{\mathrm{g}}=1.7\right)$ in the morning and $1.15\left(\sigma_{\mathrm{g}}=1.48\right)$ in the afternoon. Similar fine mode GMD values have been found in other studies carried out by Anderson et al. [1996] (mid-South Atlantic), Le Canut et al. [1996] (southern Africa), or Reid et al. [1998] (Brazil). These authors registered values of $0.17 \mu \mathrm{m}\left(\sigma_{\mathrm{g}}=1.3\right)$ for plumes of 5 or more days; $0.15 \mu \mathrm{m}$ for "source region" plumes, and $0.19 \mu \mathrm{m}\left(\sigma_{\mathrm{g}}=1.63\right)$ for plumes older than 2 3 days. In these studies, particle numbers of 200, 1,000, and $5,000 \mathrm{~cm}^{-3}$ were registered, respectively. Gassó and Hegg [1998] (North America), Formenti et al. [2002]
(Greece), and Fiebig et al. [2003] (Germany) found higher values: $0.24,0.20$, and $0.23 \mu \mathrm{m}$, with deviations of $1.40,1.43$, and $1.45 \mu \mathrm{m}$, for plumes aged between $1.8 \mathrm{~h}$, over 6 days, and 6-7 days, in forest fires with 25,600, 1,800 , and $220-250 \mathrm{~cm}^{-3}$, respectively. On the other hand, studies carried out by Reid and Hobbs [1998] (Brazil) in plumes only a few minutes old with over $150,000 \mathrm{~cm}^{-3}$ found diameter values of $0.10 \mu \mathrm{m}$ and deviations between 1.77 and $1.91 \mu \mathrm{m}$. Strictly speaking, these measurements cannot be compared directly, as the environmental conditions, vegetation, plume age, measurement techniques, and
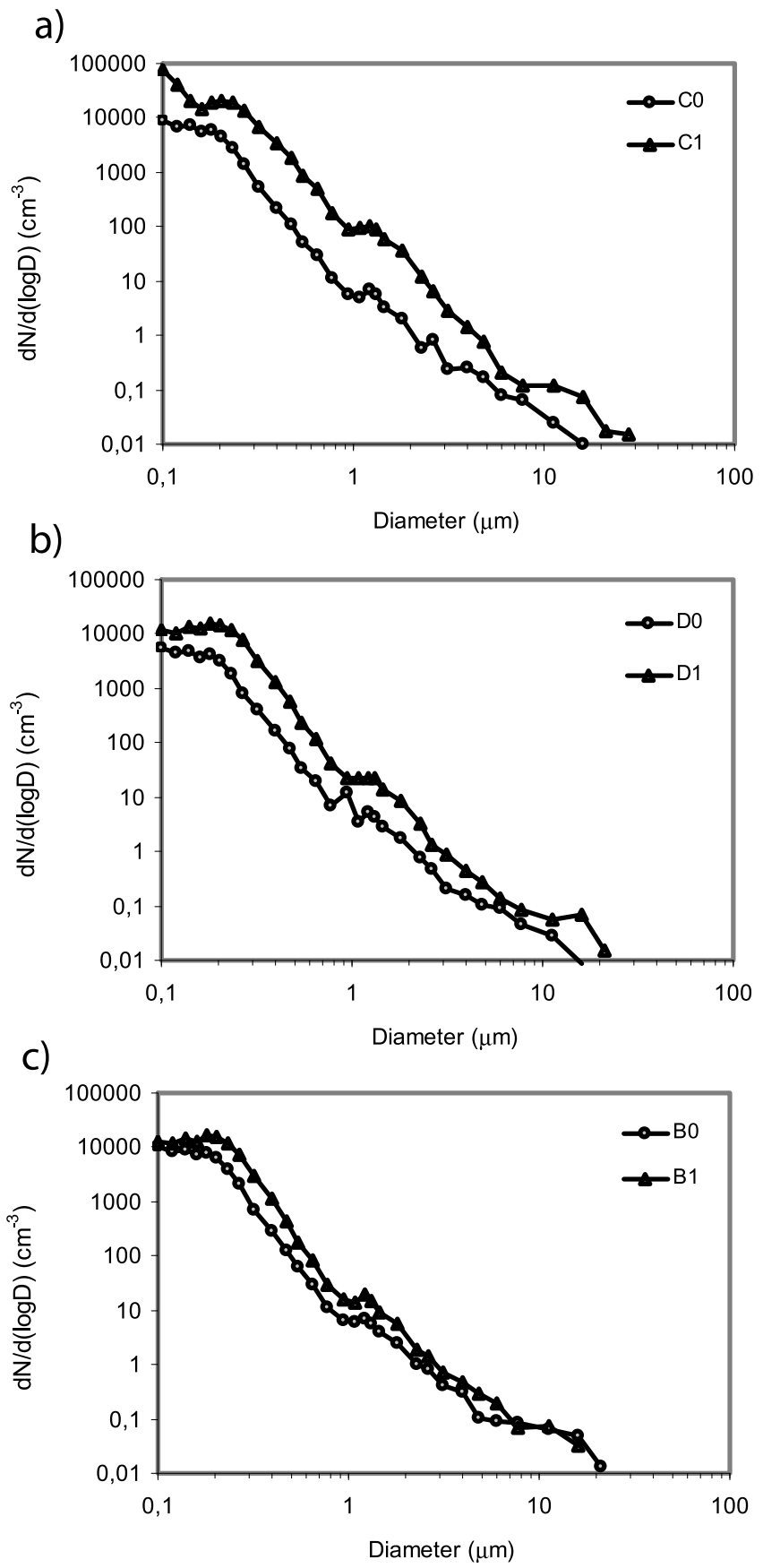

Figure 5. Aerosol size spectrum in Villablino on 7 September in the morning and in the afternoon for (a) sampling point $C$, (b) sampling point $D$, and (c) sampling point $B$. 
Table 5. Instantaneous Direct Clear-Sky Radiative Forcing of Aerosols $\left(\mathrm{W} / \mathrm{m}^{2}\right)$ and Associated Heating Rate $(\mathrm{K} / \mathrm{d})$, Calculated With MODIS AOD on 7 September 2000 at 1125 UTC

\begin{tabular}{ccrrrr}
\hline $\begin{array}{c}\text { Sampling } \\
\text { Points }\end{array}$ & Time (UTC) & $\Delta \mathrm{F}_{\mathrm{BOA}}$ & \multicolumn{1}{c}{$\Delta \mathrm{F}_{\mathrm{TOA}}$} & $\Delta \mathrm{F}_{\mathrm{ATM}}$ & $\mathrm{HER}$ \\
\hline B0 & 1150 & $-74.0 \pm 8.8$ & $-6.03 \pm 1.2$ & $+68.0 \pm 10.9$ & +9.1 \\
B1 & 1650 & $-67.6 \pm 8.1$ & $-23.4 \pm 4.7$ & $+44.2 \pm 7.1$ & +5.3 \\
C0 & 1226 & $-67.4 \pm 8.1$ & $-8.3 \pm 1.7$ & $+59.1 \pm 9.5$ & +7.7 \\
C1 & 1554 & $-68.9 \pm 8.3$ & $-16.4 \pm 3.3$ & $+52.5 \pm 8.4$ & +6.6 \\
D0 & 1307 & $-80.4 \pm 9.6$ & $+4.9 \pm 1.0$ & $+85.3 \pm 13.6$ & +11.9 \\
D1 & 1625 & $-71.2 \pm 8.5$ & $-21.9 \pm 4.4$ & $+49.3 \pm 7.9$ & +5.9 \\
\hline
\end{tabular}

normalization methods (if applied) are different. However, they do provide an overview of the information about particle emission in forest fires and their aging processes.

[37] Comparing the results between the morning (0) and the afternoon (1) samples shows that GMD in the morning, without thermal inversion, ranged between 0.11 and $0.13 \mu \mathrm{m}$ for the fine mode, and between 1.15 and $1.20 \mu \mathrm{m}$ for the coarse mode (see Table 4). In the afternoon, with the thermal inversion, GMD ranged between $0.15 \mu \mathrm{m}$ and $0.19 \mu \mathrm{m}$ for the fine mode, and was $1.15 \mu \mathrm{m}$ for the coarse mode. This means that under thermal inversion, when the valley filled with smoke haze, mainly fine particles grew in size in the aging process. At point $\mathrm{C}$, the closest to the fire, fine aerosol increased from 0.13 to $0.19 \mu \mathrm{m}$ in $3.5 \mathrm{~h}$.

[38] Hobbs et al. [1996] reported that over a $2 \mathrm{~h}$ period during a very large and intense fire, the GMD for freshly generated smoke increased from 0.16 to $0.28 \mu \mathrm{m}$. Moreover, Abel et al. [2003] observed dramatic changes in smoke particle microphysics in less than $2 \mathrm{~h}$ after the emission. Gas-to-particle conversion may be as important as coagulation in influencing particle size during the smoke aging process. For smoke particles, gas-to-particle conversion has at least three components: (1) near-source condensation of primary low vapor pressure organics, (2) production of inorganic particulate matter, and (3) gas-to-particle conversion of organics [Reid et al., 2005]. These freshly generated secondary particles are defined as ultrafine particles, with a size below the lower limit of the PCASP sampler. As a result, these gas-to-particle conversion processes cannot be included in this discussion. They are mentioned here because after coagulation and condensation processes, these initially fine particles could partly explain the increase in the number concentration and growth of the GMD. Moreover, discussions on the effect of simultaneous condensation and coagulation on accumulation mode particle size are found in the work of Turco and Fangqun [1999]. Reid et al. [1998], in their analysis of Brazilian forest fire smoke, suggested that the principal mechanisms for the growth of regional smoke particles (1-4 days old) were both condensation and particle coagulation, and that after about 3 days of aging, coagulation would probably become the dominant mechanism. From visual observations, assuming that the intensity of the fires does not change, coagulation and condensation processes can be considered as dominant mechanisms in the evolution of the number-size distributions of the advected sampled air. As a result of these processes, the aging phase enhances the scattering ability of fine aerosols as SSA values increase, regardless of the wavelengths considered between morning and afternoon.
[39] Our simulations allowed us to investigate the surface SW forcing during the fire. The instantaneous surface SW forcing $(\triangle \mathrm{FBOA})$ estimated by GAME (Table 5 ) may reach up to between $-80.4 \pm 9.6$ and $-67.4 \pm 8.1 \mathrm{~W} / \mathrm{m}^{2}$. These values are consistent with those simulated by Formenti et al. [2002] in the STAAARTE MED 1998 experiment. In fact, for AOD values of around 0.3 and a refractive index of $1.55-0.025 \mathrm{i}$, over sea surface and over sea plus vegetation surface the daytime averages of direct radiative forcing at the surface were $-55 \pm 20$ and $-49 \pm 16 \mathrm{~W} / \mathrm{m}^{2}$, respectively. Furthermore, considering diurnal cycles [Formenti et al., 2002, Figure 10], the intensity of instantaneous radiative forcings varied to a low degree around these averages. A significant decrease of solar energy of this type at the surface may strongly modify the surface energy budget. Latent heat and sensible heat fluxes from the surface are consequently disturbed as mentioned by Feingold et al. [2005]. Furthermore, the reduction in surface latent and sensible heat fluxes associated with biomass burning impact could reduce cloudiness [Jiang and Feingold, 2006].

[40] Moderate instantaneous SW $\triangle$ FTOA values (Table 5) were calculated by GAME, reaching up to $-23.4 \pm 4.7$ and $+4.9 \pm 1.0 \mathrm{~W} / \mathrm{m}^{2}$. For comparison, these instantaneous values are found to be similar with those obtained by Formenti et al. [2002] in the case studies described above, with daytime averages of direct radiative forcing at TOA of $-21( \pm 7)$ and $-12( \pm 5) \mathrm{W} / \mathrm{m}^{2}$, respectively. For most of our case studies, the aerosol forcing is negative (cooling effect at TOA) and much higher at the surface than at the TOA, owing to absorption. Only one case differs from this pattern (case D0 in Table 5) and is discussed below.

[41] Also, the absorption of solar radiation in the atmosphere by the smoke aerosol is indicated by positive instantaneous SW $\triangle$ FATM provided by GAME, considered with quite low SSA values (see Table $3 b$ ), ranging from $+44.2 \pm 7.1$ to $+85.3 \pm 13.6 \mathrm{~W} / \mathrm{m}^{2}$. These important positive radiative forcings reveal an atmospheric heating by absorbing particles, which may affect cloud cover and planetary albedo [Ackerman et al., 2000] as well as atmospheric stability [Hodzic et al., 2007].

[42] The SW Heating Rate (HER; K/d) computed with GAME allows us to quantify the potential heating for the whole atmospheric column, as if the fire conditions were persistent. Our daily HER values ranged from +5.3 to $+11.9 \mathrm{~K} / \mathrm{d}$. For a zenith angle of $60^{\circ}$, Pace et al. [2005] computed comparable SW HER for forest fire aerosol over the Mediterranean basin, at surface level only, with lower AOD than our value $(0.25$ at $415.6 \mathrm{~nm})$, low SSA $(0.83$ at $415.6 \mathrm{~nm})$, and a similar $g$ value $(0.63$ at $415.6 \mathrm{~nm})$. HER was estimated at around $+1.7 \mathrm{~K} / \mathrm{d}$.

[43] In the following, the evolution of the radiative forcing is discussed in relation to the variability of optical properties. Table 5 shows that only one value of instantaneous TOA forcing is positive $\left(+4.9 \pm 1.0 \mathrm{~W} / \mathrm{m}^{2}\right)$. This reveals a warming effect at the top of the atmosphere induced by the presence of smoke aerosols. If we compare the optical properties at the different measurement points, only SSA values for the whole size distribution differ greatly from one to another. Irrespective of the wavelengths considered, SSA presents very low values $(0.81,0.81$, and 0.77 for 440,670 , and $870 \mathrm{~nm}$, respectively; see Table $3 \mathrm{~b}$ ), conferring a maximum absorption property to the smoke layer. Cooling 
effects encountered in most of the sampling points shift to warming for these aerosol SSA values. For a given surface albedo (here, 0.14 from AERONET retrieval over Palencia), the change of sign of the aerosol-induced forcing reveals that the critical aerosol SSA value has been reached [Haywood and Shine, 1995; Russell et al., 2002]. This sensitivity of radiative fluxes to aerosol SSA may affect heating rates, surface temperatures, atmospheric stability, and cloud formation and persistence [Russell et al., 2002]. Also, the maximal HER was estimated for the D0 point $(+11.9 \mathrm{~K} / \mathrm{d})$. This variability of the aerosol SSA can be explained by the presence of the lowest value of GMD $(0.11 \mu \mathrm{m})$ for the fine mode for the AOD considered $(\mathrm{AOD}=0.31)$, revealing a more absorbing fine aerosol.

[44] For the different sampling points B1, C1, and D1, regardless of the distance to the fire, under thermal inversion the aged smoke haze in the valley produced an important attenuation of incoming solar energy and a stronger cooling effect at the top of the atmosphere than were measured in the morning. In three sampling points in the valley, the mean HER associated with the smoke haze was estimated at $5.9 \pm$ $0.6 \mathrm{~K} / \mathrm{d}$, which could affect the local dynamic stability.

\section{Conclusions}

[45] The aim of this study was to estimate radiative forcings of a smoke haze from field measurements performed during a fire event in northwestern Spain, in which, between morning and afternoon samplings, a thermal inversion occurred, preventing smoke and gases from dispersing above the boundary layer. This study determined the aging speed of fine aerosol over a short time span: a growth of $0.06 \mu \mathrm{m}$ for GMD of the fine mode was measured for a period of $3.5 \mathrm{~h}$. On the basis of several hypotheses on gathered data, the SW radiative forcings at surface level, at top level, and in the atmosphere were computed. Estimated instantaneous surface forcing can reach up to between -80.4 and $-67.4 \mathrm{~W} / \mathrm{m}^{2}$, instantaneous TOA forcing up to between -23.4 and $+4.9 \mathrm{~W} / \mathrm{m}^{2}$, and instantaneous atmosphere forcing up to between +44.2 and $+85.3 \mathrm{~W} / \mathrm{m}^{2}$. Radiative atmosphere forcings indicate the absorption of solar radiation in the atmosphere by smoke aerosols with quite low SSA values. In one specific case, smoke aerosol SSA exceeded the critical value related to surface albedo, and the smoke aerosol layer should behave for SW like a greenhouse gas layer for long waves by generating a positive instantaneous TOA forcing. Moreover, thanks to radiative forcing, we can say that aging processes confer aerosols a greater scattering ability. As a result, for this specific haze condition in the valley, the mean heating rate was estimated at $5.9 \pm 0.6 \mathrm{~K} / \mathrm{d}$. This estimation of heating seems useful, as fire events in northwestern Spain and the North of Portugal are highly frequent. They are likely to affect regional atmospheric stability, heating rates, surface temperatures, cloud formation, and precipitation. Future modeling exercises at a regional scale should allow us to estimate these parameters for regional climatic feedbacks.

[46] Acknowledgments. The authors would like to thank José L. Sánchez and Laura López for their cooperation in the project, and Antonio M. Ortín for his help with the graphs. We are also grateful to Noelia Ramón for translating this paper into English and to Roberto Collazos for his help in setting up the final format of the paper. The data for the analysis were kindly provided by the Department for the Environment (Junta de Castilla y León). The authors are especially indebted to Miguel Ángel Olguín, from the office responsible for forest fires in the regional government. We would also like to thank Victoria Cachorro Revilla for providing the AERONET data in Palencia.

\section{References}

Abel, S., J. Haywood, J. Li, and P. Buseck (2003), Evolution of biomass burning aerosol properties from an agricultural fire in South Africa, Geophys. Res. Lett., 30(15), 1783, doi:10.1029/2003GL017342.

Ackerman, A. S., O. B. Toon, D. E. Stevens, A. J. Heymsfield, V. Ramanathan, and E. J. Welton (2000), Reduction of tropical cloudiness by soot, Science, 288, 1042-1047, doi:10.1126/science.288.5468.1042.

Anderson, B. E., W. B. Grant, G. L. Gregory, E. V. Browell, J. E. Collins, G. W. Sachse, D. R. Bagwell, C. H. Hudgins, D. R. Blake, and N. J. Blake (1996), Aerosols from biomass burning over the tropical South Atlantic region: Distributions and impacts, J. Geophys. Res., 101, 24,11724,137, doi:10.1029/96JD00717.

Andreae, M. O., B. E. Anderson, D. R. Blake, J. D. Bradshaw, J. E. Collins, G. L. Gregory, G. W. Sachse, and M. C. Shipham (1994), Influence of plumes from biomass burning on atmospheric chemistry over the equatorial and tropical South Atlantic during CITE 3, J. Geophys. Res., 99, 12,793-12,808, doi:10.1029/94JD00263.

Bohren, C. F., and D. R. Huffman (1983), Absorption and Scattering of Light by Small Particles, 544 pp., Wiley, New York.

Cachorro, V. E., P. Duran, R. Vergaz, and A. M. de Frutos (2000), Columnar physical and radiative properties of atmospheric aerosols in north central Spain, J. Geophys. Res., 105, 7161-7175, doi:10.1029/1999JD901165.

Chylek, P., and J. Wong (1995), Effect of absorbing aerosols on global radiation budget, Geophys. Res. Lett., 22(8), 929-931, doi:10.1029/ 95GL00800.

Crutzen, P. J., and M. O. Andreae (1990), Biomass burning in the tropics: Impact on atmospheric chemistry and biogeochemical cycles, Science, 250, 1669-1678, doi:10.1126/science.250.4988.1669.

Dubovik, O., B. Holben, T. F. Eck, A. Smirnov, Y. J. Kaufman, M. D. King, D. Tanré, and I. Slutsker (2002), Variability of absorption and optical properties of key aerosol types observed in worldwide locations, J. Atmos. Sci., 59(3), 590-608.

Dubuisson, P., J. C. Buriez, and Y. Fouquart (1996), High spectral resolution solar radiative transfer in absorbing and scattering media: Application to the satellite simulation, J. Quant. Spectrosc. Radiat. Transfer, 55, 103-126, doi:10.1016/0022-4073(95)00134-4.

Dubuisson, P., D. Dessailly, M. Vesperini, and R. Frouin (2004), Water vapor retrieval over ocean using near-infrared radiometry, J. Geophys. Res., 109, D19106, doi:10.1029/2004JD004516.

Feingold, G., H. Jiang, and J. Y. Harrington (2005), On smoke suppression of clouds in Amazonia, Geophys. Res. Lett., 32, L02804, doi:10.1029/ 2004GL021369.

Ferge, T., J. Maguhn, K. Hafner, F. Muhlberger, M. Davidovic, R. Warnecke, and R. Zimmermann (2005), On-line analysis of gas phase composition in the combustion chamber and particle characteristics during combustion of wood and waste in a small batch reactor, Environ. Sci. Technol., 39(6), 1393-1402, doi:10.1021/es049493o.

Fiebig, M., A. Stohl, M. Wendisch, S. Eckhardt, and A. Petzol (2003), Dependence of solar forcing of forest fire aerosol on aging and state of mixture, Atmos. Chem. Phys., 3, 881-891.

Formenti, P., et al. (2002), STAAARTE-MED 1998 summer airborne measurements over the Aegean Sea: 2. Aerosol scattering and absorption, and radiative calculations, J. Geophys. Res., 107(D21), 4451, doi:10.1029 2001JD001536.

Gassó, S., and D. A. Hegg (1998), Comparison of columnar aerosol optical properties measured by the MODIS airborne simulator with in situ measurements: A case study, Remote Sens. Environ., 66, 138-152, doi:10.1016/S0034-4257(98)00052-2.

Halthore, R. N., et al. (2005), Intercomparison of shortwave radiative transfer codes and measurements, J. Geophys. Res., 110, D11206, doi:10.1029/2004JD005293.

Haywood, J., and K. Shine (1995), The effect of anthropogenic sulfate and soot aerosol on the clear sky planetary radiation budget, Geophys. Res Lett., 22(5), 603-606, doi:10.1029/95GL00075.

Haywood, J. M., S. R. Osborne, P. N. Francis, A. Keil, P. Formenti, M. O. Andreae, and P. H. Kaye (2003), The mean physical and optical properties of regional haze dominated by biomass burning aerosol measured from the C-130 aircraft during SAFARI 2000, J. Geophys. Res., 108 (D13), 8473, doi:10.1029/2002JD002226.

Hobbs, P. V., J. S. Reid, J. A. Herring, J. D. Nance, R. E. Weiss, J. L. Ross, D. A. Hegg, R. D. Ottmar, and C. Liousse (1996), Particle and trace-gas measurements in the smoke from prescribed burns of forest products in 
the Pacific northwest, in Biomass Burning and Global Change, vol. 2, edited by J. S. Levine, pp. 697-715, MIT Press, Cambridge, Mass.

Hobbs, P. V., J. S. Reid, R. A. Kotchenruther, R. J. Ferek, and R. Weiss (1997), Direct radiative forcing by smoke from biomass burning, Science, 275, 1777-1778, doi:10.1126/science.275.5307.1777.

Hobbs, P. V., P. Sinha, R. J. Yokelson, T. J. Christian, D. R. Blake, S. Gao, T. W. Kirchstetter, T. Novakov, and P. Pilewskie (2003), Evolution of gases and particles from a savanna fire in South Africa, J. Geophys. Res., 108(D13), 8485, doi:10.1029/2002JD002352.

Hodzic, A., S. Madronich, B. Bohn, S. Massie, L. Menut, and C. Wiedinmyer (2007), Wildfire particulate matter in Europe during summer 2003: Mesoscale modeling of smoke emissions, transport and radiative effects, Atmos. Chem. Phys., 7, 4043-4064.

Holzworth, G. C. (1967), Mixing depths, wind speeds and air pollution potential for selected locations in the United States, J. Appl. Meteorol., 6, 1039-1044, doi:10.1175/1520-0450(1967)006<1039:MDWSAA>2.0. $\mathrm{CO} ; 2$.

Huebert, B., L. Zhuang, S. Howell, K. Noone, and B. Noone (1996), Sulfate, nitrate, methanesulfonate, chloride, ammonium, and sodium measurements from ship, island, and aircraft during the Atlantic Stratocumulus Transition Experiment/Marine Aerosol Gas Exchange, J. Geophys. Res., 101, 4413-4423, doi:10.1029/95JD02044.

Ikegami, M., K. Okada, Y. Zaizen, Y. Makino, J. B. Jensen, J. L. Gras, and $\mathrm{H}$. Harjanto (2001), Very high weight ratios of $\mathrm{S} / \mathrm{K}$ in individual haze particles over Kalimantan during the 1997 Indonesian forest fires, Atmos. Environ., 35, 4237-4243, doi:10.1016/S1352-2310(01)00247-3.

Intergovernmental Panel on Climate Change (2001), Climate Change 2001: The Scientific Basis, Cambridge Univ. Press, New York.

Intergovernmental Panel on Climate Change (2007), Climate Change 2007: The Physical Basis of Climate Change, edited by J. T. Houghton et al., Cambridge Univ. Press, New York.

Jiang, H., and G. Feingold (2006), Effect of aerosol on warm convective clouds: Aerosol-cloud-surface flux feedbacks in a new coupled large eddy model, J. Geophys. Res., 111, D01202, doi:10.1029/2005JD006138.

Le Canut, P., M. O. Andreae, G. W. Harris, F. G. Wienhold, and T. Zenker (1996), Aerosol optical properties over southern Africa during SAFARI-92, in Biomass Burning and Global Change, edited by J. S. Levine, pp. 1, 42, 441-459, MIT Press, Cambridge, Mass.

Lee, K. H., J. E. Kim, Y. J. Kim, J. Kim, and W. von Hoyningen-Huene (2005). Impact of the smoke aerosol from Russian forest fires on the atmospheric environment over Korea during May 2003, Atmos. Environ., 39, 85-99, doi:10.1016/j.atmosenv.2004.09.032.

Lin, J. C., T. Matsui Sr., R. A. Pielke Sr., and C. Kummerow (2006), Effects of biomass-burning-derived aerosols on precipitation and clouds in the Amazon Basin: A satellite-based empirical study, J. Geophys. Res., 111, D19204, doi:10.1029/2005JD006884.

Liousse, C., C. Devaux, F. Dulac, and H. Cachier (1995), Aging of savanna biomass burning aerosols: Consequences on their optical properties, J. Atmos. Chem., 22, 1-17, doi:10.1007/BF00708178.

Mallet, M., V. Pont, C. Liousse, J. C. Roger, and P. Dubuisson (2006), Simulation of aerosol radiative properties with the ORISAM-RAD model during a pollution event (ESCOMPTE 2001), Atmos. Environ., 40, 7696 7705, doi:10.1016/j.atmosenv.2006.08.031.

Mallet, M., et al. (2008), Aerosol direct radiative forcing on Djougou (northern Benin) during the African Monsoon Multidisciplinary Analysis dry season experiment (Special Observation Period-0), J. Geophys. Res., 113, D00C01, doi:10.1029/2007JD009419.

Pace, G., D. Meloni, and A. di Sarra (2005), Forest fire aerosol over the Mediterranean basin during summer 2003, J. Geophys. Res., 110, D21202, doi:10.1029/2005JD005986.

Penner, J. E., R. E. Dickinson, and C. A. O’Neill (1992), Effects of aerosols from biomass burning on the global radiation budget, Science, 256 , 1432-1434, doi:10.1126/science.256.5062.1432.
Procopio, A. S., L. A. Remer, P. Artaxo, Y. J. Kaufman, and B. N. Holben (2003), Modeled spectral optical properties for smoke aerosols in Amazonia, Geophys. Res. Lett., 30(24), 2265, doi:10.1029/2003GL018063.

Radke, L. F., A. S. Hegg, P. V. Hobbs, and J. E. Penner (1995), Effects of aging on the smoke from a large forest-fire, Atmos. Res., 38, 315-332, doi:10.1016/0169-8095(95)00003-A.

Reid, J. S., and P. V. Hobbs (1998), Physical and optical properties of young smoke from individual biomass fires in Brazil, J. Geophys. Res., 103, 32,013-32,030, doi:10.1029/98JD00159.

Reid, J. S., P. V. Hobbs, R. J. Ferek, D. R. Blake, J. V. Martins, M. R. Dunlap, and C. Liousse (1998), Physical, chemical, and optical properties of regional hazes dominated by smoke in Brazil, J. Geophys. Res., 103, 32,059-32,080, doi:10.1029/98JD00458.

Reid, J. S., R. Koppmann, T. F. Eck, and D. P. Eleuterio (2005), A review of biomass burning emissions part II: Intensive physical properties of biomass burning particles, Atmos. Chem. Phys., 5, 799-825.

Roger, J. C., M. Mallet, P. Dubuisson, H. Cachier, E. Vermote, O. Dubovik, and S. Despiau (2006), A synergetic approach for estimating the local direct aerosol forcing: Application to an urban zone during the Expérience sur Site pour Contraindre les Modèles de Pollution et de Transport d'Emission (ESCOMPTE) experiment, J. Geophys. Res., 111, D13208, doi:10.1029/2005JD006361.

Russell, P. B., et al. (2002), Comparison of aerosol single scattering albedos derived by diverse techniques in two North Atlantic experiments, J. Atmos. Sci., 59(3), 609-618, doi:10.1175/1520-0469(2002)059<0609: COASSA $>2.0 . \mathrm{CO} ; 2$.

Stamnes, K., S. Tsay, W. Wiscombe, and K. Jayaweera (1988), Numerically stable algorithm for discrete-ordinate-method radiative transfer in multiple scattering and emitting layered media, Appl. Opt., 27, 2502-2509, doi:10.1364/AO.27.002502.

Turco, R. P., and Y. Fangqun (1999), Particle size in an expanding plume undergoing simultaneous coagulation and condensation, J. Geophys. Res., 104, 19,227-19,241.

von Hoyningen-Huene, W., T. Schmidt, A. K. Chan, J. Heintzenberg, and C. Neusuess (1998), Climate-relevant aerosol parameters of South-EastAsian forest fire haze, J. Aerosol Sci., 29, 1259-1260, doi:10.1016/ S0021-8502(98)90812-6.

Wardoyo, A. Y. P., L. Morawska, Z. D. Ristovski, M. Jamriska, S. Carr and G. Johnson (2007), Size distribution of particles emitted from grass fires in the Northern Territory, Australia, Atmos. Environ., 41, 86098619, doi:10.1016/j.atmosenv.2007.07.020.

Wendisch, M., J. Heintzenberg, and M. Busserner (2001), Measurementbased aerosol forcing calculation: The influence of model complexity, Meteorol. Z., 10, 45-60, doi:10.1127/0941-2948/2001/0010-0045.

Westphal, D. L., and O. B. Toon (1991), Simulations of microphysical, radiative, and dynamic processes in a continental-scale forest-fire smoke plume, J. Geophys. Res., 96, 22,379-22,400, doi:10.1029/91JD01956.

Wieser, U., and C. Gaegauf (2005), Nanoparticle emissions of wood combustion processes, report, Center of Appropriate Technol. and Social Ecol., Lab. for Sustainable Energy Syst., Langenbruck, Switzerland. Yamasoe, M. A., Y. J. Kaufman, O. Dubovik, L. A. Remer, B. N. Holben, and P. Artaxo (1998), Retrieval of the real part of the refractive index of smoke particles from Sun/sky measurements during SCAR-B, J. Geophys. Res., 103, 31,893-31,902.

A. I. Calvo, A. Castro, R. Fraile, and C. Palencia, Departamento de Física, Universidad de León, León E-24071, Spain. (roberto.fraile@unileon.es) P. Dubuisson, Laboratoire d'Optique Atmosphérique, Université des Sciences et Technologies de Lille, 59655 Villeneuve d'Ascq, Lille, France. M. Mallet and V. Pont, Laboratoire d'Aérologie, OMP, Université de Toulouse III, 14, Ave. E. Belin, F-31400 Toulouse, France.

J. C. Roger, Laboratoire de Meteorologie Physique, OPGC, F-63177 Aubière, France. 